\title{
Krzysztof Kolatka
}

Uniwersytet Kazimierza Wielkiego w Bydgoszczy

\section{Ojkonimy świadectwem językowego, kulturowego, historycznego i przyrodniczego dziedzictwa Krajny}

\section{O roli toponimów}

Toponimia, podobnie jak inne działy onomastyki (zwłaszcza antroponimia i chrematonimia), stanowi od dawna niebywale popularną dziedzinę badawczą, i to nie tylko na gruncie polskiej lingwistyki ${ }^{1}$. Prymarnym celem dociekań uczonych, w obrębie owej subdyscypliny, jest dwutorowa analiza nazw geograficznych, uwzględniająca zarówno płaszczyznę semantyczną, jak i formalną. Najogólniej ujmując, zmierza ona przede wszystkim do ustalenia właściwej etymologii oraz scharakteryzowania budowy onimów. Ponadto rozważania toponomastów koncentrują się w znacznej mierze na próbach klasyfikacji toponimów, a także określeniu terytorialnego rozmieszczenia i frekwencji ich typów na danym obszarze, wyodrębnionych na podstawie klasycznych kryteriów, a mianowicie: semantyczno-etymologicznego Witolda Taszyckiego [zob. idem 1946] oraz strukturalno-gramatycznego Stanisława Rosponda [zob. idem 1957].

Jednak nawet najbardziej rzetelne i wyczerpujące opracowanie tych zagadnień wcale nie oznacza, że praca onomasty została ukończona. Uzyskane dane można bowiem interpretować w rozmaity sposób. Otóż rola nazw geograficznych,

${ }^{1}$ O tym, jak bardzo eksploatowane jest to pole, niechaj świadczy m.in. ogromna liczba publikacji z tego zakresu [zob. np.: Belchnerowska 1995; Bijak 2001a, 2001b; Biolik 1992; Borek 1968, 1972, 1988; Breza 1974; Bugalska 1985; Chludziński 2008, 2009; Czopek 1988; Czopek-Kopciuch 1995; Domański 1967; Górnowicz 1968a, 1968b, 1980, 1985; Halicka 1976, 1978; Hrabec 1950; Iwicki 1993; Jakus-Borkowa 1987; Kamińska 1964-1965; Karaś 1955; Kęsikowa 1976; Kondratiuk 1973; Kopertowska 1984, 1994; Kosyl 1978; Lubaś 1968; Łuszczyńska 1983; Makarski 1986, 1999; Milewska-Stawiany 2000; Mrózek 1984; Nieckula 1971; NGŚ; NMPol; NMPG; Orzechowska 1975; Pawłowski 1971, 1975; Podlawska 1990; Pospiszylowa 1987; Rospond 1951, 1957, 1969 , 1974, 1976, 1984; Rudnicki 1939; Rymut 1967, 1971, 1973, 1975, 1980; Rzetelska-Feleszko 1978; Rzetelska-Feleszko, Duma 1985, 1991, 1996; Safarewiczowa 1956; Stieber 1948-1949; Surma 1990; Szcześniak 1994; Taszycki 1946, 1951; Treder 1977a, 1977b; Urbańczyk 1965; Warchoł 1964; Wójcik 2001; Zierhoffer 1957; Zierhofferowa 1989; Zierhofferowie 1987]. 
a właściwie wszystkich jednostek leksykalnych reprezentujących kategorię nomina propria, nie jest zredukowana wyłącznie do pełnienia funkcji wyróżniającej, deiktycznej, lokalizującej.

Pośród wielu cennych wypowiedzi - wyartykułowanych w podobnym tonie - warto przytoczyć tu słowa Zofii Kalety. Uczona konstatuje mianowicie, iż: „Nazwy własne są bogactwem każdego narodu, gdyż kryją w sobie wiedzę o jego historii politycznej i społecznej, o historii kultury i religii, właściwościach i krajobrazie ziemi rodzinnej, o związkach z innymi krajami, a także o działaniach, dążeniach, a nawet emocjach ludzi, jak również o realiach życia oraz ludzkich wartościach. Są też świadectwem przynależności etnicznej człowieka i ziemi do narodu, wyznacznikiem narodowości" [Kaleta 1998: 15].

$\mathrm{Z}$ tej perspektywy toponimy jawią się również jako nieocenione źródło informacji na temat danego terytorium. W nazwach geograficznych bowiem, niczym w zwierciadle, odbija się jego językowy, społeczno-kulturowy, dziejowy, a także przyrodniczy wizerunek. Ojkonimy, anojkonimy, urbonimy, urbanonimy, hydronimy bądź oronimy to swoiste magazyny, rezerwuary, dzięki którym może on zostać utrwalony. Toponimia Krajny nie jest w tym przypadku wyjątkiem.

Celem niniejszego artykułu jest fragmentaryczna rekonstrukcja obrazu tegoż regionu, pod kątem przywołanych założeń, na podstawie wybranych krajeńskich ojkonimów, tj. nazw miast, wsi, osad oraz kolonii²

\section{Krajeńskie ojkonimy jako zwierciadło językowego, kulturowego, historycznego i przyrodniczego dziedzictwa Krajny}

Biorąc pod uwagę fakt, iż kwestia granic Krajny, zarówno w dyskursie naukowym, jak i potocznym, w dalszym ciągu wywołuje wiele wątpliwości, nieporozumień i kontrowersji, niepodobna w tym miejscu nie wyznaczyć jej dokładnego kształtu terytorialnego, zwłaszcza w sytuacji, w której przedmiot zainteresowania stanowią nazwy miejscowe.

Przyjmuję mianowicie, że współcześnie obszar tego regionu jako krainy historycznej o określonym dziejowym, kulturowym, językowym oraz przyrodniczym obliczu jest tożsamy z terytorium Krajny historycznej, pokrywającym się $\mathrm{z}$ terenem dawnego, przedrozbiorowego, powiatu nakielskiego [zob. np.: Callier 1886: 1-3; Krajna-Wielatowski 1928: 23; Szafran 1961: 26, 28-29]³. Jego ramy

${ }^{2}$ Ekscerpcji materiału dokonałem na podstawie trzytomowego Wykazu urzędowych nazw miejscowości w Polsce [WUNM], a także własnych obserwacji, jakie przeprowadziłem w ramach badań terenowych w latach 2010-2012.

${ }^{3}$ Problematykę granic Krajny, charakteryzując zarazem wybrane stanowiska z zakresu historii, geografii, etnografii oraz językoznawstwa, poruszyłem już w innym artykule [zob. Kołatka 2011: 60-68]. 
geograficzne mają charakter naturalny, gdyż zasadniczo wyznaczają je linie rzek: Gwdy od zachodu, Noteci od południa, a także Debrzynki i Kamionki od północy. Wyjątek stanowi wschodnie pogranicze, przebiegające od północy wzdłuż doliny Brdy, następnie pasmem jezior koronowskich (nieopodal wsi Kamienica, Pruszcz i osady Motyl) oraz drogą lądową, obejmując takie miejscowości, jak: Mąkowarsko, Lucim, Wilcze, Łąsko Wielkie, Łąsko Małe, Wierzchucin Królewski, Krąpiewo, Słupowo, Gliszcz, Samsieczno, Gumnowice, Trzeciewnica oraz Nakło nad Notecią [por. m.in. Callier 1886: 3].

Tak widziane terytorium Krajny współcześnie położone jest w obrębie trzech województw, a mianowicie: kujawsko-pomorskiego (powiat bydgoski: m.in. wsie - Lucim, Łąsko Wielkie, Mąkowarsko, Samsieczno, Wierzchucin Królewski, Wilcze; powiat nakielski: Mrocza, Nakło nad Notecią; powiat sępoleński: Kamień Krajeński, Sępólno Krajeńskie, Więcbork; powiat tucholski: m.in. wsie - Bagienica, Kamienica, Pruszcz, Wielka Klonia), pomorskiego (powiat człuchowski: wsie - Buka, Drozdowo, Poręba, Stare Gronowo), a także wielkopolskiego (powiat pilski: Łobżenica, Wyrzysk, Wysoka; powiat złotowski: Krajenka, Złotów).

Krajna usytuowana jest zatem na styku dwóch - pod wieloma względami barwnych - makroregionów: Wielkopolski i Pomorza. W dalszej perspektywie owa wyjątkowa lokalizacja zadecydowała o dziejowej, kulturowej i językowej specyfice regionu. Ziemia ta bowiem już od stuleci stanowi miejsce ścierania się językowych i kulturowych kaszubsko-pomorskich oraz wielkopolskich wpływów. Nie ulega wątpliwości, iż ów fakt ukształtował jej heterogeniczny, przejściowy charakter.

Innym niezwykle istotnym czynnikiem, rzutującym bezspornie na charakterystyczny wizerunek terytorium i determinującym jego rozwój, były bardzo intensywne, a niekiedy nawet burzliwe, stosunki polsko-niemieckie. Otóż Krajniacy koegzystowali z ludnością obcego pochodzenia już od wieków średnich. Ów stan rzeczy stanowił konsekwencję kilku fal niemieckiego osadnictwa, najazdów krzyżackich, a także wielu lat zniewolenia pod zaborem pruskim. Trzeba tu również dodać, że po I wojnie światowej, na mocy wersalskiego traktatu pokojowego (1919 r.), Krajna została podzielona granicą państwową. Zachodnią część regionu wcielono do Niemiec, wschodnią natomiast włączono do nowo powstałej II Rzeczypospolitej.

\subsection{Obraz językowy}

Najliczniejszą reprezentację stanowią w tej grupie ojkonimy wywodzące się od dawnych i gwarowych nazw osobowych oraz apelatywnych. Toponimy zawierające historyczne i dialektalne właściwości fonetyczne, a także morfologiczne występują zdecydowanie rzadziej. Przeważają tu nazwy dzierżawcze oraz topograficzne. 
a) nazwy miejscowe ilustrujące dawne i dialektalne cechy fonetyczne oraz morfologiczne polszczyzny: Buka (wieś, woj. pomorskie, pow. człuchowski, gm. Debrzno): Nowawies sive Buko (1615) $\rightarrow$ Nowa Wiesz sive Buk (1618$1620) \rightarrow$ Villa Nowawies sive Buk $(1766) \rightarrow$ Buk//Buka//(niem. Boeck) $(1880)$ $\rightarrow$ Buka//(niem. Böck) (1951) $\rightarrow$ Buka (1980) - od dawnej postaci przymiotnika niezłożonego buk [NMPol I]; Czarmuń (wieś, woj. kujawsko-pomorskie, pow. sępoleński, gm. Więcbork): Czarnom (1430) $\rightarrow$ Czarnow (1511-1512) $\rightarrow$ Czarnom $(1578,1618-1620) \rightarrow$ Czarnon (1640-1644) $\rightarrow$ Czarłom $(1653)$ $\rightarrow$ Czartum $(1695) \rightarrow$ Czarnoń (1708) $\rightarrow$ Czartoń (1766) $\rightarrow$ Czarnuń $(1880)$ $\rightarrow$ Czarmuń//(niem. Hohensee) (1921) $\rightarrow$ Czarmuń (1971) - asymilacja grup $-r n-\rightarrow-r t$ - oraz $t-\dot{n} \rightarrow n-\dot{n}$, dysymilacja $n-\dot{n} \rightarrow m-\dot{n}$, adideacja do nazw zakończonych na -oń, podwyższenie artykulacji samogłoski o przed spółgłoską nosową [NMPol II] [zob. p. 2.1.c)]; Dziedno (wieś, woj. kujawsko-pomorskie, pow. sępoleński, gm. Sośno): Dzadowo//Dzedno//Zedno (1300) $\rightarrow$ Zedno magno $(1325) \rightarrow$ Dzedno $(1359) \rightarrow$ Zedno Magnum $(1368) \rightarrow$ in maiori Dzedno $(1413) \rightarrow$ Dzedzno $(1534) \rightarrow$ Dziedno $(1578) \rightarrow$ Villa Dziednio $(1766) \rightarrow$ Dzidno $(1846) \rightarrow$ Dzidno//Dziedno $(1881) \rightarrow$ Dziedno $(1972)$ - brak przegłosu $\check{e} \rightarrow$ 'a [NMPol II]; Falmierowo (wieś, woj. wielkopolskie, pow. pilski, gm. Wyrzysk): Chwalimirowo $(1402) \rightarrow$ Qualmerow $(1413) \rightarrow$ Chwalimirowo $(1493) \rightarrow$ Phalymyrowo $(1511-1512) \rightarrow$ Falimirowo $(1548) \rightarrow$ Falimierowo $(1565) \rightarrow$ Falmierowo $(1578) \rightarrow$ Falmierow $(1618-1620) \rightarrow$ Falmierowo $(1661) \rightarrow$ Villa Falmierowo $(1766) \rightarrow$ Falmirowo $(1846) \rightarrow$ Falmierowo $/ /$ (niem. Charlottenburg) (1875) $\rightarrow$ Falmierowo//(niem. Charlottenburg) (1921) $\rightarrow$ Falmierowo (1972) - zmiana nagłosowej cząstki chw-w $f$-, zanik śródgłosowej samogłoski $i$, przejście grupy -ir-w -er- [Malec 2003: 77; NMPol III] [zob. p. 2.1.c)]; Lobżenica (miasto, woj. wielkopolskie, pow. pilski, gm. Łobżenica): Lopszencz//Lobszenecz (1398) $\rightarrow$ Lobszenica $(1427) \rightarrow$ Lobszencza $(1430) \rightarrow$ Lobzenycza $(1441) \rightarrow$ Lobżenica $(1467) \rightarrow$ Lobdzenycza $(1511-1523) \rightarrow$ Lobzencza $(1565) \rightarrow$ Lobzenicza $(1578) \rightarrow$ Eobzenica $(1618-1620,1673) \rightarrow$ in Civitate Lobzynica $(1744) \rightarrow$ Lobzenica $(1766) \rightarrow$ Lobżenica $(1846) \rightarrow$ Lobżenical/(niem. Lobsens) $(1884,1921) \rightarrow$ Eobżenica $(1972)$ - mieszanie szeregów spółgłoskowych $z, \dot{z}, \dot{z}$ [Malec 2003: 149; NMPol VI; Rospond 1984: 204] [zob. p. 2.1.b)]; Sepólno Krajeńskie (miasto, woj. kujawsko-pomorskie, pow. sępoleński, gm. Sępólno Krajeńskie): Sampolno (1311) $\rightarrow$ Sampelno $(1350) \rightarrow$ (niem. de Sampulburg) (1388) $\rightarrow$ (niem. de Sampelborg) (ok. 1520) $\rightarrow$ (niem. Sempelborg) (1732) $\rightarrow$ Villa Sampolna $(1774) \rightarrow$ Sępólno//(niem. Sempelbork) (1889) $\rightarrow$ Sẹpólno Krajeńskie (1965) - zmiana samogłoski nosowej a na ę oraz podwyższenie artykulacji samogłoski $o$ do $o$ [Malec 2003: 216; zob. Czaplicka 2005: 76; Rospond 1984: 344] [zob. p. 2.1.b); p. 2.4.a)]; Wyrzysk (miasto, woj. wielkopolskie, pow. pilski, gm. Wyrzysk): (niem. Wyritz (1320)) $\rightarrow$ Wirziska $(1403) \rightarrow$ Wyrzysko $(1444) \rightarrow$ Wyrzisk $(\mathrm{XV}$ w.) $\rightarrow$ Verzyska $(1535) \rightarrow$ Wyrzysko $(1578) \rightarrow$ Werzysko//Wyrzysk $(1653) \rightarrow$ Wyrzysk (1895) - artykulacja nagłoso- 
wej cząstki $W i$ - jako $W y$ - w wyniku wymowy samogłoski $y$ jak $i^{4}$ [zob. Malec 2003: 270].

b) nazwy miejscowe utrwalające dawną i gwarową leksykę: Bialośliwie (wieś, woj. wielkopolskie, pow. pilski, gm. Białośliwie): drugi komponent złożenia od stp. i gw. czasownika śliwać 'zlewać' (śliwki 'zlewki') [NMPolI; Rospond 1984: 24]; Ciosek (osada, woj. kujawsko-pomorskie, pow. sępoleński, gm. Sośno): pośrednio od gw. leksemu ciosek 'kociuba, ożóg, kostur' ( $\rightarrow$ nazwa osobowa Ciosek//Ciosk) [NMPol II; por. Czaplicka 2005: 78]; Debrzno-Wieś (wieś, woj. wielkopolskie, pow. złotowski, gm. Lipka): od stp. leksemu debrz//debrza 'mały wąwóz utworzony przez wodę, zarośnięty' (psł. przymiotnik *dzbrbnъ 'nisko położony, w dolinie, w parowie') [NMPol II; Rospond 1984: 70]; Drążno (wieś, woj. kujawsko-pomorskie, pow. nakielski, gm. Mrocza): od psł. rzeczownika *dręzga 'las błotnisty' [NMPol II]; Dziegciarnia (wieś, woj. wielkopolskie, pow. pilski, gm. Łobżenica): od leksemu dziegciarz (psł. *degbtařb 'człowiek zajmujący się wyrobem (sprzedażą) dziegciu') lub rzeczownika dziegieć [NMPol II] [zob. p. 2.2.b)]; Dźwierszno (Dźwierszno Male, Dźwierszno Wielkie) (wsie, woj. wielkopolskie, pow. pilski, gm. Łobżenica): od przymiotnika *dźwirstny (stp. dźwiarstwo 'gruby piasek, żwir'; drzastwo//drząstwo 'drobne kamyki, teren kamienisty') [NMPol II]; Gliszcz (wieś, woj. kujawsko-pomorskie, pow. bydgoski, gm. Sicienko): od leksemu gliszcze 'popielisko po spaleniu zwłok', prawdopodobnie także 'każde popielisko, także po wypaleniu lasu' [NMPol III]; Gmurowo (wieś, woj. wielkopolskie, pow. pilski, gm. Wysoka): pośrednio od rzeczownika gmur 'chłop, wieśniak, kmieć, włościanin, chłop osiadły, właściciel gruntu, gospodarz, posiadający własny grunt’ $(\rightarrow$ nazwisko Gmur) [NMPol III]; Kawle (wieś, woj. kujawsko-pomorskie, pow. sępoleński, gm. Sępólno Krajeńskie): od gw. leksemu kawel lub kawet//kawla 'niwa, pole na niwy podzielone; części pola; kawał pola' [Czaplicka 2005: 77; NMPol IV] [zob. p. 2.4.a)]; Kietpin (wieś, woj. wielkopolskie, pow. złotowski, gm. Lipka): pośrednio od gw. leksemu kietp 'gatunek ryby' lub 'labędź' ( $\rightarrow$ nazwa rzeki Kietpina, nazwa jeziora Kietpin) [NMPol IV]; Kościerzyn (Kościerzyn Mały, Kościerzyn Wielki) (wsie, woj. wielkopolskie, pow. pilski, gm. Łobżenica): od gw. rzeczownika kuoscër 'drzewo bardzo rozgałęzione, zarośla, krzewy' (lub od antroponimu $\operatorname{Kościer(z))~[NMPol~V];~Kruszki~(wieś,~woj.~wielkopolskie,~pow.~pilski,~gm.~Ło-~}$ bżenica): od apelatywu kruszka 'gruszka' (bądź antroponimu Gruszka//Kruszka) [NMPol V] [zob. p. 2.1.c)]; Kujan (wieś, woj. wielkopolskie, pow. złotowski, gm. Zakrzewo): pośrednio od stp. leksemu kujan 'nicpoń, łajdak, ladaco, dureń' ( $\rightarrow$ nazwa jeziora Kujan) [NMPol V]; Lobżenica (miasto, woj. wielkopolskie, pow. pilski, gm. Łobżenica): od apelatywu *tobez//łobzina ' roślina bagienna, zarośla

${ }^{4}$ Według Stanisława Rosponda, trwałe przejście nagłosowej grupy $W i$ - w $W y$-nastąpiło pod wpływem niemieckiej artykulacji tegoż ojkonimu [Rospond 1984: 440].

${ }^{5}$ W gwarach południowej Krajny do dzisiaj funkcjonuje słowo łabuzie//łobuzie, oznaczające 'zarośla, krzaki; tatarak'. 
występujące na terenie podmokłym' [Malec 2003: 149; NMPol VI; Rospond 1984: 204] [zob. p. 2.1.a)]; Miasteczko-Huby (wieś, woj. wielkopolskie, pow. pilski, gm. Miasteczko Krajeńskie): drugi człon zestawienia - huby - to 'gospodarstwo wybudowane w polu, kolonia' [NMPol VII] [zob. p. 2.2.b)]; Naklo nad Notecia (miasto, woj. kujawsko-pomorskie, pow. nakielski, gm. Nakło nad Notecią): od wyrazu *nakieł, którego czeski ekwiwalent nákel oznacza 'miejsce podmokłe, zwłaszcza z niskimi zaroślami wierzbowymi' (nákli ‘młode zarośla wiklinowe', 'miejsce przy wodzie, gdzie się krzewi wierzbina; miejsce bagniste; náklo 'miejsce przy rzece; miejsce do wyładunku towarów') [Malec 2003: 164; NMPol VII; Rospond 1984: 241]; Osiek nad Notecia (wieś, woj. wielkopolskie, pow. pilski, gm. Wyrzysk): od stp. leksemu osiek 'umocnienie obronne wznoszone ze ściętych drzew, przesiekę, zasiek' [Malec 2003: 181; NMPol VIII]; Sępólno Krajeńskie (miasto, woj. kujawsko-pomorskie, pow. sępoleński, gm. Sępólno Krajeńskie): od psł. wyrazu *sapolbje 'pole leżące obok innego pola, graniczące z czym, pograniczne', złożonego z dawnego przyimka sa i rzeczownika pole [Malec 2003: 216; Rospond 1984: 166, 344] [zob. p. 2.1.a); p. 2.4.a)]; Sypniewo (wieś, woj. kujawsko-pomorskie, pow. sępoleński, gm. Więcbork): od stp. leksemu sypien 'wielki drewniany lej, przez który sypano zboże'; Tarnówka (wieś, woj. wielkopolskie, pow. złotowski, gm. Tarnówka): od stp. rzeczownika tarn 'cierń, tarnina' [Rospond 1984: 395] (lub od nazwy osobowej); Wawelno (wieś, woj. kujawsko-pomorskie, pow. sępoleński, gm. Sośno): od stp. leksemu wawel 'grąd, suche, wyniosłe miejsce w otoczeniu podmokłym lub w otoczeniu łąk błotnistych, ostrów oblany wodą' [Czaplicka 2005: 76-77; Rospond 1984: 418] [zob. p. 2.4.a)].

c) nazwy miejscowe wywodzące się od staropolskich antroponimów: $\boldsymbol{B} \boldsymbol{a}$ $\operatorname{decz}$ (wieś, woj. wielkopolskie, pow. pilski, gm. Wysoka): od antroponimu Bądek ( $\leftarrow$ Będzieciech//Będziemir) [NMPol I]; Buczek (Maly Buczek, Nowy Buczek, Wielki Buczek) (wsie, woj. wielkopolskie, pow. złotowski, gm. Lipka): od nazwy osobowej Buszek [NMPol I]; Chwalka (wieś, woj. kujawsko-pomorskie, pow. nakielski, gm. Mrocza): od antroponimu Chwatek w formie dopełniaczowej ( $\leftarrow$ Chwalibor) [NMPol II]; Ciosek [zob. p. 2.1.b)]; Czarmuń (wieś, woj. kujawsko-pomorskie, pow. sępoleński, gm. Więcbork): od nazwy osobowej *Czarnom [NMPol II] [zob. p. 2.1.a)]; Dalkowo (wieś, woj. kujawsko-pomorskie, pow. sępoleński, gm. Więcbork): od antroponimu Dalek $(\leftarrow$ Dalebor) [Czaplicka 2005: 78; NMPol II]; Falmierowo (wieś, woj. wielkopolskie, pow. pilski, gm. Wyrzysk): od nazwy osobowej Falimir//Kwalimir ( $\leftarrow$ Chwalimir) [zob. Malec 2003: 77; NMPol III] [zob. p. 2.1.a)]; Fanianowo (wieś, woj. wielkopolskie, pow. pilski, gm. Łobżenica): od antroponimu *Fanian ( $\leftarrow$ Eufemian//Eufamian) [NMPol III]; Jaszkowo (wieś, woj. kujawsko-pomorskie, pow. sępoleński, gm. Sośno): od nazwy osobowej Jaszek//Jaszk [NMPol IV]; Komierowo (wieś, woj. kujawsko-pomorskie, pow. sępoleński, gm. Sępólno Krajeńskie): od antroponimu Komir [Czaplicka 2005: 78; NMPol V]; Kruszki [zob. p. 2.1.b)]; Lubcza (wieś, woj. kujawsko-pomorskie, pow. sępoleński, gm. Więcbork): od antroponi- 
Ojkonimy świadectwem językowego, kulturowego, historycznego i przyrodniczego... 195

mu Lubek [NMPol VI]; Lucim (wieś, woj. kujawsko-pomorskie, pow. bydgoski, gm. Koronowo): od nazwy osobowej * Lucim ( $\leftarrow$ Lutomir) [NMPol VI]; Lutowo (wieś, woj. kujawsko-pomorskie, pow. sępoleński, gm. Sępólno Krajeńskie): od nazwy osobowej Lut [NMPol VI; por. Czaplicka 2005: 76]; Młotkowo (wieś, woj. wielkopolskie, pow. pilski, gm. Wysoka): od antroponimu Młodek [NMPol VII]; Morzewo (wieś, woj. wielkopolskie, pow. pilski, gm. Kaczory): od nazwy osobowej Morz//Morza [NMPol VII]; Niechorz (wieś, woj. kujawsko-pomorskie, pow. sępoleński, gm. Sępólno Krajeńskie): od antroponimu *Niechor [Czaplicka 2005: 78; NMPol VII]; Witostaw (wieś, woj. kujawsko-pomorskie, pow. nakielski, gm. Mrocza): od imienia Witosław; Włościbórz (wieś, woj. kujawsko-pomorskie, pow. sępoleński, gm. Sępólno Krajeńskie): od antroponimu Włościbor [Czaplicka 2005: 78].

\subsection{Obraz kulturowy}

Zebrane tu toponimy, obejmujące nazwy kulturowe, dotyczą zarówno kultury duchowej, jak i społeczno-materialnej.

a) nazwy miejscowe związane z kulturą duchową: Cerkwica (Duża Cerkwica, Mała Cerkwica) (wsie, woj. kujawsko-pomorskie, pow. sępoleński, gm. Kamień Krajeński): od apelatywu cerkiew [NMPol II]; Diabli Kąt (osada, woj. kujawsko-pomorskie, pow. sępoleński, gm. Sępólno Krajeńskie): od wyrazów diabet i kąt [Czaplicka 2005: 78]; Dwanaście Apostotów (osada, woj. kujawsko-pomorskie, pow. sępoleński, gm. Więcbork): od parafii rzymskokatolickiej pw. Dwunastu Apostołów [Czopek-Kopciuch 1995: 86; NMPol II]; Górka Klasztorna (wieś, woj. wielkopolskie, pow. pilski, gm. Łobżenica): od znajdującego się we wsi, najstarszego w Polsce, miejsca kultu maryjnego; mieści się tam klasztor Księży Misjonarzy Świętej Rodziny [NMPol III].

b) nazwy miejscowe związane z kulturą społeczno-materialną: Dziegciarnia [zob. p. 2.1.b)]; Gliszcz [zob. p. 2.1.b)]; Gmurowo [zob. p. 2.1.b)]; Miasteczko-Huby [zob. p. 2.1.b)]; Młynowo (osada, woj. wielkopolskie, pow. pilski, gm. Łobżenica): od apelatywu młyn; Osiek nad Notecia [zob. p. 2.1.b)]; Sadki (wieś, woj. kujawsko-pomorskie, pow. nakielski, gm. Sadki): od leksemu sad (lub od antroponimu); Sypniewo [zob. p. 2.1.b)].

\subsection{Obraz historyczny}

Ojkonimy w tej kategorii stanowią w znacznej mierze ślad dawnej podległości Krajny wobec państwa niemieckiego. Wyodrębnić tu można nazwy miejscowe powstałe od antroponimów o obcej proweniencji, a także toponimy niemieckie, które uległy (re)polonizacji albo po 1918 r. (w przypadku Krajny wschodniej), albo po 1945 r. (w odniesieniu do Krajny zachodniej). 
a) nazwy miejscowe wywodzące się od antroponimów o niemieckim pochodzeniu: Buntowo (wieś, woj. wielkopolskie, pow. złotowski, gm. Złotów): od nazwy osobowej Bunt [NMPol I]; Lubaszcz (wieś, woj. kujawsko-pomorskie, pow. nakielski, gm. Nakło nad Notecią): od dopełniaczowej formy antroponimu *Lubarts $(\leftarrow$ Lubart $\leftarrow$ Laubert $)[\mathrm{NMPol} \mathrm{VI}]$.

b) nazwy miejscowe zrepolonizowane:

- brak związku z pierwotną nazwą: Auguścin (wieś, woj. wielkopolskie, pow. pilski, gm. Wyrzysk): Dąbrówka//niem. Augustenhof (1875) $\rightarrow$ Augustowo//niem. Augustenhof $(1880) \rightarrow$ Auguścin//niem. Augustenhof $(1921) \rightarrow$ Auguścin (1972) [Czopek-Kopciuch 1995: 97; NMPol I]; Więcbork (miasto, woj. kujawsko-pomorskie, pow. sępoleński, gm. Więcbork): Vanzowna $(1288) \rightarrow$ Wanszowna $(1383) \rightarrow$ Wieczbork//niem. Vandsburg $(1405) \rightarrow$ Wiandzborek// niem. Vandsburg (XV w.) $\rightarrow$ Vyaczborg//niem. Vandsburg (1512) $\rightarrow$ Viazowno $(1546) \rightarrow$ Więcbork//niem. Vandsburg $(1612) \rightarrow$ Więcborg//niem. Vandsburg (1766) $\rightarrow$ niem. Vansburg (1819) $\rightarrow$ Więcbork//niem. Vandsburg (1893) [Czaplicka 2005: 77; Czopek-Kopciuch 1995: 84; Malec, 2003: 262; Rospond 1984: 425];

- związek z pierwotną nazwą: Biegodzin (osada, woj. wielkopolskie, pow. pilski, gm. Łobżenica): Biezdziedzin $(1745,1746) \rightarrow$ Będziedzin (1749) $\rightarrow$ Biegodzin//niem. Begedorf (1846) $\rightarrow$ Begedzin//niem. Begedorf (1859) $\rightarrow$ Biegodzyn// niem. Begedorf $(1880) \rightarrow$ Biegodzin $(1967,1980)$ [NMPol I]; Katarzyniec (wieś, woj. kujawsko-pomorskie, pow. sępoleński, gm. Więcbork): Katarzynowo//niem. Katharinendorf $(1882) \rightarrow$ Katarzyniec//niem. Katharinendorf $(1921) \rightarrow$ Katarzyniec (1971, 1981) [Czopek-Kopciuch 1995: 86; NMPol IV]; Żuławka (wieś, woj. wielkopolskie, pow. pilski, gm. Wyrzysk): Żuławka (1846) $\rightarrow$ niem. Zickwerder $(1875) \rightarrow$ Zykwajdy//niem. Zickwerder (1895) $\rightarrow$ Żuławka (1982) [ibidem: 84].

c) nazwy miejscowe spolonizowane:

- brak związku z nazwą niemiecką: Czernice (wieś, woj. wielkopolskie, pow. złotowski, gm. Zakrzewo): niem. Koenigsdorf (1883) $\rightarrow$ Czernice//niem. Königsdorf (1951) $\rightarrow$ Czernice (1980) [NMPol II]; Drozdowo (wieś, woj. pomorskie, pow. człuchowski, gm. Debrzno): niem. Posenberg $(1880) \rightarrow$ Drozdowo//niem. Posenberg $(1951) \rightarrow$ Drozdowo $(1952,1980)$ [NMPol II]; Drożyska (Drożyska Małe, Drożyska Średnie, Drożyska Wielkie) (wsie, woj. wielkopolskie, pow. złotowski, gm. Zakrzewo): niem. Friedrichsberg wielki, mały $i$ śred$n i(1881) \rightarrow$ Drożyska Małe, Średnie, Wielkie $(1928) \rightarrow$ Drożyska Małe//niem. Klein Friedrichsberg, Drożyska Średnie//niem. Mittel Friedrichsberg, Drożyska Wielkie//niem. Gross Friedrichsberg (1951) $\rightarrow$ Drożyska Małe, Drożyska Średnie, Drożyska Wielkie (1980) [NMPol II]; Laskowo (wieś, woj. wielkopolskie, pow. złotowski, gm. Lipka): niem. Annenfelde (1880) $\rightarrow$ Laskowo//niem. Annenfelde $(1949,1951) \rightarrow$ Laskowo (1981) [NMPol VI];

- adaptacja lub kalka nazwy niemieckiej: Arentowo (wieś, woj. wielkopolskie, pow. pilski, gm. Miasteczko Krajeńskie): niem. Arendtwalde (1846) $\rightarrow$ niem. Arent- 
Ojkonimy świadectwem językowego, kulturowego, historycznego i przyrodniczego... 197

swalde $(1875) \rightarrow$ niem. Arndswalde $(1880) \rightarrow$ Arentowo//niem. Arnswalde (1921) $\rightarrow$ Arentowo (1972) [Czopek-Kopciuch 1995: 92; NMPol I]; Bialoblocie (wieś, woj. wielkopolskie, pow. złotowski, gm. Lipka): niem. Wilhelmsbruch (imię Wilhelm + der Bruch 'bagno, moczary') (1893) $\rightarrow$ Białobłocie//niem. Wilhelmsbruch (1951) $\rightarrow$ Białobłocie (1980) [NMPol I]; Blękwit (wieś, woj. wielkopolskie, pow. złotowski, gm. Złotów): Vlugfelth (1432-1440) $\rightarrow$ Bløquelth//Bløqwelth $(1453) \rightarrow$ Blankwith (1491) $\rightarrow$ Blankwyelth (XV w.) $\rightarrow$ Blankwit $(1503) \rightarrow$ Blankfelt//Blawelth (1511-1512) $\rightarrow$ Blankfyeyth (1535) $\rightarrow$ Blankwelt $(1578) \rightarrow$ Blekuid (1593) $\rightarrow$ Blękwid (1604) $\rightarrow$ Blenkwida//Blekwit $(1653) \rightarrow$ Blękwit//Btękwida//Blankwitt $(1880) \rightarrow$ Blękwit//Blankwitt (1951) $\rightarrow$ Blękwit (1980) [Czopek-Kopciuch 1995: 88-89; NMPol I] ${ }^{6}$; Dworzakowo (wieś, woj. wielkopolskie, pow. pilski, gm. Białośliwie): niem. Hofmannsdorf (nazwisko Hoffmann + das Dorf 'wieś') (1882) $\rightarrow$ Dworzakowo//niem. Hoffmannsdorf (1921) $\rightarrow$ Dworzakowo (1972) [Czopek-Kopciuch 1995: 96; NMPol II]; Frydrychowo (kolonia, woj. kujawsko-pomorskie, pow. sępoleński, gm. Więcbork): niem. Friedrichsau $(1881) \rightarrow$ Fredrykowo//niem. Fridrichsau $(1921) \rightarrow$ niem. Friedrichsau $(1933) \rightarrow$ Frydrykowo $(1967) \rightarrow$ Frydrychowo (1971) [Czopek-Kopciuch 1995: 98; NMPol III]; Maryniec (wieś, woj. wielkopolskie, pow. złotowski, gm. Krajenka): niem. Marienwalde (1885) $\rightarrow$ Maryniec//niem. Marienwalde (1921) $\rightarrow$ Maryniec (1981) [Czopek-Kopciuch 1995: 98; NMPol VI]; Matyldzin (wieś, woj. kujawsko-pomorskie, pow. nakielski, gm. Mrocza): niem. Mathildenhoehe $(1885) \rightarrow$ niem. Mathildenhöhe $(1907) \rightarrow$ Matyldowo (1912) $\rightarrow$ Matyldzin//niem. Mathildenhöhe $(1921) \rightarrow$ Matyldzin $(1933,1967,1972)$ [Czopek-Kopciuch 1995: 98; NMPol VI]; Szynwald (wieś, woj. kujawsko-pomorskie, pow. sępoleński, gm. Sośno): niem. Schönwalde (1867) $\rightarrow$ Szynwatd//niem. Schönwalde (1921) [Czopek-Kopciuch 1995: 91]; Waldowo (wieś, woj. kujawsko-pomorskie, pow. sępoleński, gm. Sępólno Krajeńskie): niem. de Valdow (1289) $\rightarrow$ w Wałdowie (1439) [Czopek-Kopciuch 1995: 94; por. np. Czaplicka 2005: 76].

\subsection{Obraz przyrodniczy}

Na grupę ojkonimów rejestrujących bogactwo krajeńskiego krajobrazu składają się nazwy topograficzne wskazujące na rzeźbę terenu, jego cechy oraz florę i faunę.

a) nazwy miejscowe odzwierciedlające ukształtowanie i właściwości terenu: Bagienica (wieś, woj. kujawsko-pomorskie, pow. tucholski, gm. Gostycyn): od przymiotnika bagienny [NMPol I]; Bielawy (wieś, woj. kujawsko-pomorskie, pow. nakielski, gm. Nakło nad Notecią): od rzeczownika bielawa 'podmokła

${ }^{6}$ Ojkonim Blękwit odzwierciedla także, właściwe gwarom krajeńskim, zjawiska fonetyczne, a mianowicie artykulację spółgłoski $f$ jako $v$ ' oraz zwężenie samogłoski $e$ do $i$ po spółgłosce miękkiej [Czopek-Kopciuch 1995: 88].

${ }^{7}$ Niemiecki apelatyw der Hofman przetłumaczyć można jako 'dworzanin, dworak'. 
łąka torfowa' [NMPol I]; Chlebno (wieś, woj. wielkopolskie, pow. pilski, gm. Łobżenica): od przymiotnika chlebny 'urodzajny' [NMPol II]; Dabrowa (wieś, woj. kujawsko-pomorskie, pow. sępoleński, gm. Kamień Krajeński): od leksemu dąbrowa 'las dębowy; dębina' [Malec 2003: 66; NMPol II]; Debrzno-Wieś [zob. p. 2.1.b)]; Drażno [zob. p. 2.1.b)]; Dźwierszno (Dźwierszno Małe, Dźwierszno Wielkie) [zob. p. 2.1.b)]; Ilowo (wieś, woj. kujawsko-pomorskie, pow. sępoleński, gm. Sępólno Krajeńskie): od rzeczownika it 'drobnoziarnista, różnie zabarwiona skała osadowa' [Czaplicka 2005: 76; NMPol III]; Kawle [zob. p. 2.1.b)]; Nakto nad Notecia [zob. p. 2.1.b)]; Piaseczno (wieś, woj. kujawsko-pomorskie, pow. sępoleński, gm. Sępólno Krajeńskie): od apelatywu piasek [NMPol VIII]; Polanowo (wieś, woj. wielkopolskie, pow. pilski, gm. Wyrzysk): od rzeczownika polana [NMPol IX]; Puszcza (wieś, woj. kujawsko-pomorskie, pow. sępoleński, gm. Więcbork): od apelatywu puszcza [NMPol IX]; Sepólno Krajeńskie [zob. p. 2.1.a); p. 2.1.b)]; Skarpa (wieś, woj. kujawsko-pomorskie, pow. sępoleński, gm. Sępólno Krajeńskie): od wyrazu skarpa [Czaplicka 2005: 76]; Stawnica (wieś, woj. wielkopolskie, pow. złotowski, gm. Złotów): od leksemu staw; Wawelno [zob. p. 2.1.b)];

b) nazwy miejscowe pochodne od nazw roślin: Brzostowo (wieś, woj. wielkopolskie, pow. pilski, gm. Miasteczko Krajeńskie): od rzeczownika brzost 'wysokie drzewo liściaste' [NMPol I]; Dębowo (wieś, woj. kujawsko-pomorskie, pow. nakielski, gm. Sadki): od wyrazu dąb [NMPol II]; Kruszki [zob. p. 2.1.b)]; Lobżenica [zob. p. 2.1.a), 2.1.b)]; Modrakowo (wieś, woj. kujawsko-pomorskie, pow. nakielski, gm. Mrocza): od leksemu modrak; Świdwie (wieś, woj. kujawsko-pomorskie, pow. sępoleński, gm. Sępólno Krajeńskie): od wyrazu świdwa 'dereń, kora jaskrawo czerwona' [Czaplicka 2005: 77; Rospond 1984: 389]; Tarnówka [zob. p. 2.1.b)]; Topola (wieś, woj. wielkopolskie, pow. pilski, gm. Łobżenica): od apelatywu topola; Wiśniewa (wieś, woj. kujawsko-pomorskie, pow. sępoleński, gm. Sępólno Krajeńskie): od rzeczownika wiśnia; Zboże (wieś, woj. kujawsko-pomorskie, pow. sępoleński, gm. Sępólno Krajeńskie): od apelatywu zboże [Czaplicka 2005: 77];

c) nazwy miejscowe wywodzące się od nazw zwierząt: Czajcze (wieś, woj. wielkopolskie, pow. złotowski, gm. Krajenka): od leksemów czajka, czajczy [NMPol II] ; Jeleń (wieś, woj. kujawsko-pomorskie, pow. sępoleński, gm. Więcbork): od rzeczownika jeleń (lub od antroponimu Jeleń) [NMPol IV]'; Kietpin [zob. p. 2.1.b)]; Orle (wieś, woj. kujawsko-pomorskie, pow. nakielski, gm. Mrocza): od rzeczownika orzet bądź przymiotnika orli [NMPol VIII]; Sikorz (wieś, woj. kujawsko-pomorskie, pow. sępoleński, gm. Sępólno Kra-

${ }^{8}$ Czajcze to także nazwa wsi w gminie Wysoka (woj. wielkopolskie, pow. pilski).

${ }^{9}$ Zdaniem Barbary Czopek-Kopciuch, ojkonim Jeleń powstał pod wpływem niemieckiej nazwy Lilienhecke, w wyniku podobieństwa dźwiękowego między jej pierwszym komponentem Lilien- - i gwarowym leksemem lelen 'jeleń' [Czopek-Kopciuch 1995: 91]. 
jeńskie): od wyrazu sikora [Czaplicka 2005: 77]; Wilkowo (wieś, woj. kujawsko-pomorskie, pow. sępoleński, gm. Sępólno Krajeńskie): od apelatywu wilk [Czaplicka 2005: 77].

\section{Uwagi końcowe}

Należy wyraźnie podkreślić, że nazwy miejscowe, będące przedmiotem niniejszej analizy, stanowią jedynie niewielką część bogactwa krajeńskiej toponimii.

Co ciekawe, w przypadku ojkonimii Krajny do rzadkości należą nazwy o charakterze dyferencjalnym. Uznać można jednak, iż funkcję taką pełni określenie krajeński, występujące jako komponent toponimów we wszystkich wariantach rodzajowych, np.: Kamień Krajeński, Miasteczko Krajeńskie, Runowo Krajeńskie, Sępólno Krajeńskie, Śmiardowo Krajeńskie, Wysoka Krajeńska.

Interesujące wnioski pozwala wysnuć i analiza przeprowadzona pod kątem strukturalnym. W odniesieniu do krajeńskich nazw miejscowych można bowiem zaobserwować swoistą przejściowość, biegunowość.

Uwagę przykuwają mianowicie ojkonimy z kontynuantami sufiksu *-bsk[zob. np. Górnowicz 1988: 46-47; Rzetelska-Feleszko 2003: 6-7]. Otóż charakterystyczny dla Pomorza, Mazowsza i wschodnich obszarów Polski formant -sk występuje przeważnie w północnej części Krajny, np.: Głomsk, Radońsk, Wersk. Na południu regionu zaś częściej spotkać można wariant -sko, typowy dla Wielkopolski, Małopolski oraz Śląska, np.: Łońsko, Pilsko, Wolsko. Odstępstwo od tej reguły stanowią takie nazwy, jak: Łąsko (Małe, Wielkie), Mąkowarsko, Stołuńsko, położone w północnej części „krainy na rubieży”, czy Wyrzysk - usytuowany na południu tego terytorium. Należy jednak dodać, że owe toponimy wykazywały na przestrzeni dziejów duże wahania sufiksalne [zob. m.in. NMPol; Rospond 1984].

Na Krajnie przeważają ponadto nazwy miejscowe zakończone na -owo, po spółgłoskach twardych, a także - 'ewo, po palatalnych, spalatalizowanych oraz stwardniałych, zamiast -ów//-'ew (Ł*-ov-//- 'ev-) [zob. np. Górnowicz 1988: 49; Rzetelska-Feleszko 2003: 5, 7], charakterystyczne dla Polski północnej, np.: Dobrzyniewo, Komorowo, Skoraczewo, Walentynowo.

Nader często pojawiają się też ojkonimy z sufiksem -in, w miejsce -ino $(\leftarrow$ *-in-), typowe dla Polski południowej i środkowej [zob. m.in. Górnowicz 1988: 49-50; Rzetelska-Feleszko 2003: 5, 7], np.: Anusin, Matyldzin, Śmielin, a także - dominujące w północno-zachodniej części kraju - formy z przyrostkiem -no, będącym rodzajowym ekwiwalentem sufiksów - 'en, -na ( $\leftarrow^{*}$-bn-) [zob. np. Górnowicz 1988: 47-48; Rzetelska-Feleszko 2003: 7], np.: Dębno, Glesno, Samsieczno. 
Nazwy własne, zwłaszcza ojkonimy, odgrywają niebagatelną rolę zarówno w badaniach językoznawczych, geograficznych, historycznych oraz edukacji regionalnej, jak i w potocznej świadomości mieszkańców danego obszaru, stając się istotnym elementem budującym poczucie lokalnej czy też regionalnej tożsamości [zob. m.in. Rzetelska-Feleszko 1993: 151-160]. Osiągnięcia onomastów winny być zatem traktowane na równi z wynikami badań przedstawicieli innych dyscyplin naukowych. Tymczasem zauważyć można, iż niekiedy marginalizuje się ów dział lingwistyki ${ }^{10}$.

Pomimo licznych publikacji z zakresu toponomastyki, krajeńska toponimia do dzisiaj nie doczekała się monografii. Pole to pozostaje więc nadal niezagospodarowane.

\section{Wykaz skrótów}

NGŚ - Nazwy geograficzne Ślaska. Stownik etymologiczny nazw geograficznych Ślaska, 1970-2011, t. I: $A-B$, Stanisław Rospond (red.), Warszawa-Wrocław; t. II-III: $C-G$, Stanisław Rospond i Henryk Borek (red.), Warszawa-Wrocław; t. IV: $H-K i$, Henryk Borek (red.), Warszawa-Wrocław; t. V-XV: Kl-Wrzes, Stanisława Sochacka (red.), Opole.

NMPG - Nazwy miast Pomorza Gdańskiego, 1978, Hubert Górnowicz i Zygmunt Brocki (red.), Wrocław-Warszawa-Kraków-Gdańsk.

NMPol - Nazwy miejscowe Polski. Historia. Pochodzenie. Zmiany, 1996-2015, t. I: A-B, Kazimierz Rymut (red.); t. II: $C-D$, Kazimierz Rymut (red.); t. III: $E-I$, Kazimierz Rymut (red.); t. IV: $J-K n$, Kazimierz Rymut (red.); t. V: $K o-K y$, Kazimierz Rymut (red.); t. VI: $L-M a$, Kazimierz Rymut (red.); t. VII: $M a-N$, Kazimierz Rymut (red.); t. VIII: $O-P n$, Kazimierz Rymut i Barbara Czopek-Kopciuch (red.); t. IX: Po- $Q$, Kazimierz Rymut i Barbara Czopek-Kopciuch (red.); t. X: $R a-R e$, Kazimierz Rymut, Barbara Czopek-Kopciuch i Urszula Bijak (red.); t. XI: $R e ̨-R s$, Kazimierz Rymut, Barbara Czopek-Kopciuch i Urszula Bijak (red.); t. XII: $R u-R \dot{z}$, Kazimierz Rymut, Barbara Czopek-Kopciuch i Urszula Bijak (red.), Kraków.

WUNM - Wykaz urzędowych nazw miejscowości w Polsce, 1980-1982, t. I-III, Warszawa.

\section{Bibliografia}

Belchnerowska Aleksandra, 1995, Toponimia byłych powiatów koszalińskiego i kołobrzeskiego, Gdańsk.

Bijak Urszula, 2001a, Nazwy miejscowe południowej części dawnego powiatu mazowieckiego, Kraków.

Bijak Urszula, 2001b, Nazwy miejscowe powiatu grójeckiego. Stownik historyczno-etymologiczny, Grójec.

${ }^{10}$ Ów stan rzeczy poświadczają chociażby błędne formy toponimów, pojawiające się w przestrzeni publicznej. 
Ojkonimy świadectwem językowego, kulturowego, historycznego i przyrodniczego... 201

Biolik Maria, 1992, Toponimia byłego powiatu ostródzkiego. Nazwy miejscowe, Gdańsk.

Borek Henryk, 1968, Zachodniosłowiańskie nazwy toponimiczne z formantem -ьn-, Wrocław.

Borek Henryk, 1972, Opolszczyzna w świetle nazw miejscowych, Opole.

Borek Henryk, 1988, Górny Ślask w świetle nazw miejscowych, Opole.

Breza Edward, 1974, Toponimia powiatu kościerskiego, Gdańsk.

Bugalska Halina, 1985, Toponimia byłych powiatów gdańskiego i tczewskiego, Wrocław.

Callier Edmund, 1886, Powiat nakielski w XVI stuleciu. Szkic geograficzno-historyczny, Poznań.

Chludziński Andrzej, 2008, Toponimia powiatu białogardzkiego, Pruszcz Gdański.

Chludziński Andrzej, 2009, Nazwy miejscowe powiatu kołobrzeskiego, Pruszcz Gdański.

Czaplicka Maria, 2005, Zróżnicowanie nazewnictwa geograficznego powiatu sępoleńskiego i regionu brodnickiego, [w:] Andrzej Stanisław Dyszak (red.), „Linguistica Bidgostiana”, vol. II, Bydgoszcz, 73-83.

Czopek Barbara, 1988, Nazwy miejscowe dawnej ziemi chetmskiej i betskiej (w granicach dzisiejszego państwa polskiego), Wrocław.

Czopek-Kopciuch Barbara, 1995, Adaptacje niemieckich nazw miejscowych w języku polskim, Kraków.

Domański Józef, 1967, Nazwy miejscowe dzisiejszego Wrocławia i dawnego okręgu wrocławskiego, Warszawa.

Górnowicz Hubert, 1968a, Rodowe nazwy miejscowe Wielkopolski, Małopolski i Mazowsza, Gdańsk.

Górnowicz Hubert, 1968b, Studia nad rodowymi nazwami miejscowymi w języku polskim na tle innych języków stowiańskich, Gdańsk.

Górnowicz Hubert, 1980, Toponimia Powiśla Gdańskiego, Gdańsk.

Górnowicz Hubert, 1985, Toponimia powiatu starogardzkiego, Wrocław.

Halicka Irena, 1976, Nazwy miejscowe środkowej i zachodniej Białostocczyzny. Dzierżawcze, patronimiczne i rodzime, Warszawa.

Halicka Irena, 1978, Nazwy miejscowe środkowej i zachodniej Białostocczyzny. Topograficzne i kulturowe, Warszawa.

Hrabec Stefan, 1950, Nazwy geograficzne Huculszczyzny, Kraków.

Iwicki Witold, 1993, Toponimia byłego powiatu stupskiego, Gdańsk.

Jakus-Borkowa Ewa, 1987, Toponimia powiatu świeckiego, Wrocław.

Kaleta Zofia, 1998, Teoria nazw własnych, [w:] Ewa Rzetelska-Feleszko (red.), Polskie nazwy własne. Encyklopedia, Warszawa-Kraków, 15-36.

Kamińska Maria, 1964-1965, Nazwy miejscowe dawnego województwa sandomierskiego, cz. I-II, Wrocław.

Karaś Mieczysław, 1955, Nazwy miejscowe typu Podgóra, Zalas w języku polskim i innych językach słowiańskich, Wrocław.

Kęsikowa Urszula, 1976, Nazwy geograficzne Pomorza Gdańskiego z sufiksem -ov-, Gdańsk.

Kołatka Krzysztof, 2011, ,Krajna? A gdzie to jest? ” Nazwa i granice Krajny jako przedmiot badań różnych dyscyplin naukowych, [w:] Maria Dombrowicz i Hanna Michniewicz-Ankiersztajn (red.), „Promotio Geographica Bydgostiensia”, t. VII: Turystyka w rozwoju regionalnym i lokalnym Krajny i Patuk, Bydgoszcz, 55-70.

Kondratiuk Michał, 1973, Nazwy miejscowe południowo-wschodniej Białostocczyzny, Lublin.

Kopertowska Danuta, 1984, Nazwy miejscowe województwa kieleckiego, Kraków.

Kopertowska Danuta, 1994, Nazwy miejscowe województwa radomskiego, Kielce.

Kosyl Czesław, 1978, Nazwy miejscowe dawnego województwa lubelskiego, Wrocław-WarszawaKraków-Gdańsk.

Krajna-Wielatowski Andrzej, 1928, Ziemia Zlotowska, Poznań.

Lubaś Władysław, 1968, Nazwy miejscowe południowej części dawnego województwa krakowskiego, Wrocław.

Łuszczyńska Jadwiga, 1983, Nazwy geograficzne Pomorza Gdańskiego z sufiksem -in-, Wrocław. 
Makarski Władysław, 1986, Nazwy miejscowości dawnej ziemi sanockiej, Lublin.

Makarski Władysław, 1999, Nazwy miejscowości dawnej ziemi przemyskiej, Lublin.

Malec Maria, 2003, Stownik etymologiczny nazw geograficznych Polski, Warszawa.

Milewska-Stawiany Małgorzata, 2000, Toponimia powiatu tucholskiego, Gdańsk.

Mrózek Robert, 1984, Nazwy miejscowe dawnego Śląsa Cieszyńskiego, Katowice.

Nieckula Franciszek, 1971, Nazwy miejscowe z sufiksami -ov-, -in- na obszarze Wielkopolski i Matopolski, Wrocław.

Orzechowska Alicja, 1975, Nazwy miejscowe dawnego powiatu pilzneńskiego oraz prawobrzeżnej części dawnych powiatów sandomierskiego i wiślickiego, Wrocław-Warszawa-KrakówGdańsk.

Pawłowski Eugeniusz, 1971, Nazwy miejscowości Sądecczyzny, cz. I: Nazwy miast, wsi, przysiótków oraz dzielnic wiejskich i miejskich, Wrocław-Warszawa-Kraków-Gdańsk.

Pawłowski Eugeniusz, 1975, Nazwy miejscowości Sądecczyzny, cz. II: Nazwy osiedli, WrocławWarszawa-Kraków-Gdańsk.

Podlawska Daniela, 1990, Nazwy miejscowe z terenu XVI-wiecznego województwa poznańskiego, cz. I-II, Słupsk.

Pospiszylowa Anna, 1987, Toponimia poludniowej Warmii. Nazwy miejscowe, Olsztyn.

Rospond Stanisław, 1951, Stownik nazw geograficznych Polski zachodniej i pótnocnej, cz. I: Polsko-niemiecka, cz. II: Niemiecko-polska, Wrocław.

Rospond Stanisław, 1957, Klasyfikacja strukturalno-gramatyczna słowiańskich nazw geograficznych, Wrocław.

Rospond Stanisław, 1969, Słowiańskie nazwy miejscowe z sufiksem -ьsk-, Wrocław.

Rospond Stanisław, 1974, Stratygrafia stowiańskich nazw miejscowych. Próbny atlas toponomastyczny, t. I: Formacje na -itjo, Wrocław.

Rospond Stanisław, 1976, Stratygrafia stowiańskich nazw miejscowych. Próbny atlas toponomastyczny, t. II: Formacje na *-ssk-. Formacja na *-ьn-, Wrocław.

Rospond Stanisław, 1984, Stownik etymologiczny miast i gmin PRL, Wrocław-Warszawa-KrakówGdańsk-Łódź.

Rudnicki Jarosław, 1939, Nazwy geograficzne Bojkowszczyzny, Lwów.

Rymut Kazimierz, 1967, Nazwy miejscowe pótnocnej części dawnego województwa krakowskiego, Wrocław-Warszawa-Kraków.

Rymut Kazimierz, 1971, Patronimiczne nazwy miejscowe w Małopolsce, Wrocław.

Rymut Kazimierz, 1973, Stowotwórstwo polskich patronimicznych nazw miejscowych z przyrostkiem *-(ov)itjo na tle zachodniostowiańskim, Kraków-Wrocław.

Rymut Kazimierz, 1975, Nazwy miejscowe dawnego powiatu bieckiego, Wrocław-Warszawa-Kraków-Gdańsk.

Rymut Kazimierz, 1980, Nazwy miast Polski, Wrocław-Warszawa-Kraków-Gdańsk.

Rzetelska-Feleszko Ewa, 1978, Rozwój i zmiany toponimicznego formantu -ica na obszarze zachodniosłowiańskim, Wrocław-Warszawa-Kraków-Gdańsk.

Rzetelska-Feleszko Ewa, 1993, Rola nazewnictwa w tworzeniu poczucia regionalnego, [w:] Kwiryna Handke (red.), Region, regionalizm - pojęcia i rzeczywistość, Warszawa, 151-160.

Rzetelska-Feleszko Ewa, 1998, Przedmowa, [w:] Ewa Rzetelska-Feleszko (red.), Polskie nazwy własne. Encyklopedia, Warszawa-Kraków, 9-11.

Rzetelska-Feleszko Ewa, 2003, Nazwy wsi i miast (ojkonimia), [w:] Ewa Rzetelska-Feleszko i Aleksandra Cieślikowa (red.), Stowiańska onomastyka. Encyklopedia, t. II, Warszawa-Kraków, 2-9.

Rzetelska-Feleszko Ewa, Duma Jerzy, 1985, Dawne słowiańskie nazwy miejscowe Pomorza Środkowego, Wrocław.

Rzetelska-Feleszko Ewa, Duma Jerzy, 1991, Dawne słowiańskie nazwy miejscowe Pomorza Szczecińskiego, Warszawa. 
Ojkonimy świadectwem językowego, kulturowego, historycznego i przyrodniczego... 203

Rzetelska-Feleszko Ewa, Duma Jerzy, 1996, Językowa przeszłość Pomorza Zachodniego. Na podstawie nazw miejscowych, Warszawa.

Safarewiczowa Halina, 1956, Nazwy miejscowe typu Mroczkowizna, Klimontowszczyzna, Wrocław.

Stieber Zdzisław, 1948-1949, Toponomastyka Łemkowszczyzny, cz. 1-2, Łódź.

Surma Genowefa, 1990, Toponimia powiatu bytowskiego, Wrocław.

Szafran Przemysław, 1961, Osadnictwo historycznej Krajny w XVI-XVIII w. (1511-1772), Gdańsk.

Szcześniak Krystyna, 1994, Nazwy miejscowości bylych powiatów gołdapskiego i oleckiego, Gdańsk.

Taszycki Witold, 1946, Stowiańskie nazwy miejscowe (Ustalenie podziału), Kraków.

Taszycki Witold, 1951, Patronimiczne nazwy miejscowe na Mazowszu, Kraków.

Treder Jerzy, 1977a, Toponimia byłego powiatu puckiego, Gdańsk.

Treder Jerzy, 1977b, Toponimia powiatu wejherowskiego, Gdańsk.

Urbańczyk Stanisław, 1965, Nazwy naszych stolic, Wrocław-Warszawa-Kraków.

Warchoł Stefan, 1964, Nazwy miast Lubelszczyzny, Lublin.

Wójcik Urszula, 2001, Nazwy miejscowe dawnego województwa rawskiego, Warszawa-Kraków.

Zierhoffer Karol, 1957, Nazwy miejscowe pótnocnego Mazowsza, Wrocław.

Zierhofferowa Zofia, 1989, Nazwy typu Osiek Mały, Koźminek $i$ inne derywowane od nazw miejscowych. Na przykładzie materiału z dawnego województwa kaliskiego, Wrocław-WarszawaKraków-Gdańsk.

Zierhofferowie Zofia, Karol, 1987, Nazwy miast Wielkopolski, Poznań.

Krzysztof Kołatka

\section{Oiconyms as the linguistic, cultural, historical and natural heritage of the Krajna region}

(Summary)

There is no doubt that toponyms constitute an unusually valuable source of knowledge about a given territory. Geographical names retain the most essential characteristics which make up their distinctive and unique images. Thus, oiconyms, anoiconyms, hydronyms or oronyms are becoming extremely important elements which build a sense of territorial identity in the inhabitants of any area. The mentioned findings also refer to the toponyms from the Krajna region. Because of many controversies concerning the precise geographical scope of this region located on the borderland between Great Poland and Pomerania, these inquiries assume that its area coincides with the borders of the old, pre-partition Nakło Poviat. The subject of the article is the analysis of the Krajna oiconyms carried out by paying special attention to the linguistic, cultural, historical and natural factors of the region. The characterization of the local names includes first of all an etymological-motivational aspect, giving special consideration to their cultural character. However, the fundamental aim of this study is an attempt to reconstruct the linguistic, cultural, historical and natural image of the Krajna region based on the names of towns, villages, settlements and colonies.

Słowa kluczowe: toponimy, ojkonimy, nazwy miejscowe, Krajna, dziedzictwo regionalne, językowy obraz regionu.

Key words: toponyms, oiconyms, local names, Krajna region, regional heritage, linguistic image of a region. 